\title{
Acute visceral leishmaniasis in a domestic cat (Felis silvestris catus) from the state of Tocantins, Brazil
}

\section{Leishmaniose visceral aguda em felino doméstico (Felis silvestris catus) do estado do Tocantins, Brasil}

\author{
Sebastiana Adriana Pereira Sousa ${ }^{1 *}$; Helcileia Dias Santos ${ }^{2}$; Cristiane América de \\ Carvalho $^{3}$; Aline Marinho Machado ${ }^{4}$, Letícia Espindola de Oliveira ${ }^{5}$; Taiã Mairon \\ Peixoto Ribeiro; ${ }^{6}$ Adriana Genelhú Carreira ${ }^{5}$; Samara Rocha Galvão \\ Silvia Minharro ${ }^{2}$; Francisca Elda Ferreira Dias²; Valéria De Sá Jayme ${ }^{8}$
}

\begin{abstract}
Visceral leishmaniasis (VL) is expanding in the Brazilian territory. Dogs are considered an important urban reservoir; however, studies have demonstrated the presence of infected cats in some Brazilian states. This report aimed to describe a case of Leishmania (Leishmania) infantum infection in a twomonth-old domestic feline from a Brazilian region with a high incidence of human visceral leishmaniasis. The analyzed samples were the cat's blood, conjunctiva, spleen, liver, popliteal, submandibular and mesenteric lymph nodes, skin, lung and kidney. The diagnostic methods were: parasitological examination, polymerase chain reaction (PCR) and an immunoflurescence antibody test (IFAT). All tissues were positive. The title obtained using the IFAT was 1:160. The animal was negative for feline immunodeficiency virus (FIV) and feline leukemia virus (FeLV). This work addresses the first case of feline leishmaniasis in the state of Tocantins, and reveals data that may contribute to the knowledge of the disease, since it has been shown to be able to develop rapidly and fatally in kittens, with the ability to infect several tissues.
\end{abstract}

Key words: Cat. Infection. Visceral leishmaniasis.

\section{Resumo}

A leishmaniose visceral (LV) encontra-se em expansão no território brasileiro. O cão é considerado um importante reservatório urbano, no entanto, estudos tem demonstrado a presença de felinos infectados em alguns estados brasileiros. Este relato objetivou descrever um caso de infecção por Leishmania (Leishmania) infantum em um felino doméstico de dois meses proveniente de uma região brasileira

\footnotetext{
1 Prof ${ }^{a}$, Universidade Federal do Sul e Sudeste do Pará, UNIFESSPA, Xinguara, PA, Brasil. E-mail: dri_eafa@hotmail.com

2 Prof $^{\text {as }}$, Universidade Federal do Tocantins, UFT, Araguaína, TO, Brasil. E-mail: hdsantos@mail.uft.edu.br; silviaminharro@ gmail.com; eldadias@uft.edu.br

3 Médica Veterinária, AnimaLe Laboratório Veterinário, AnimaLe, Araguaína, TO, Brasil. E-mail: animalelabvet@gmail.com

4 Discente, Programa de Pós-Graduação em Sanidade Animal e Saúde Pública nos Trópicos, UFT, Araguaína, TO, Brasil. E-mail: alinemarinho123@hotmail.com

5 Médica Veterinária, Clínica Veterinária Bichos e Cia, B\&C, Araguaína, TO, Brasil. E-mail: leticiaespindolavet@gmail.com; bichosecia@uol.com.br

6 Discente de Doutorado, Programa de Pós-Graduação em Ciência Animal, Universidade Federal de Goiás, UFG, Goiânia, GO, Brasil. E-mail: ribeiro.vet@mail.uft.edu.br

Médica Veterinária, UFT, Araguaína, TO, Brasil. E-mail: samavitor@yahoo.com.br

8 Prof ${ }^{\text {a }}$, Universidade Federal de Goiás, UFG, Goiânia, GO, Brasil. E-mail: valeria.mg@uol.com.br

* Author for correspondence
} 
com alta incidência de leishmaniose visceral humana. As amostras analisadas foram sangue, conjuntiva, baço, fígado, linfonodos poplíteo, submandibular e mesentérico, pele, pulmão e rim. Os métodos de diagnóstico utilizados foram: o exame parasitológico direto, a reação em cadeia pela polimerase (PCR) e a reação de imunofluorescência indireta (RIFI). Houve positividade de todos os tecidos e o animal apresentou elevada carga parasitária. O título obtido na RIFI foi de 1:160. O animal foi negativo para os vírus da imunodeficiência felina (FIV) e da leucemia felina (FeLV). Este trabalho aborda o primeiro caso de leishmaniose felina no estado do Tocantins e revela dados que podem contribuir para o conhecimento da doença, visto que esta mostrou-se capaz de se desenvolver de forma rápida e fatal em filhotes, podendo infectar vários tecidos.

Palavras-chave: Gato. Infecção. Leishmaniose visceral.

\section{Introduction}

Visceral leishmaniasis (VL) is caused by a protozoan of the species Leishmania (Leishmania) infantum Syn. L. (L.) chagasi (CHATZIS et al., 2014). Although dogs are considered an important urban reservoir of this infection, there are indications that domestic cats can present a relevant role in endemic areas (SILVA et al., 2010).

Studies in countries such as Israel and Greece show the presence of the infection in cats (CHATZIS et al., 2014; NASEREDDIN et al., 2008). In Brazil, infected domestic felines have already been observed in areas with a high incidence of canine and human VL (SILVA et al., 2010; SOBRINHO et al., 2012).

The state of Tocantins has shown a high incidence of VL, reaching 12.2/100,000 habitants in 2015. This index classifies it as the place with the highest incidence of this disease in the country (BRASIL, 2017).

Taking into account the distribution of visceral leishmaniasis in Brazil and the high infection rates observed in Tocantins State, the objective of this study was to describe the first case of $L$. (L.) infantum infection in a domestic feline from Araguaína city.

\section{Case report}

A domestic feline female, of no defined breed and about two-month-old, was treated at a veterinary clinic in the municipality of Araguaína-TO. The owner reported finding her abandoned on the streets of the city, showing signs of diarrhea.
The anamnesis showed normorexy and normodipsy. During the physical examination, the veterinarian observed a capillary filling time (CFT) of 2 seconds, the presence of hypocorat mucous membranes, a body temperature of $38.6{ }^{\circ} \mathrm{C}$ and the absence of changes during cardiopulmonary auscultation, abdominal palpation and palpation of lymph nodes. In addition, no skin and/or mucous lesions were observed.

Then, blood samples were collected for blood counts, which verified hyperchromic normocytic anemia (hemocytes: $4.98 \times 10^{6} / \mathrm{mm}^{3}$; hematocrit: 18.2\%; hemoglobin: $6.6 \mathrm{~g} / \mathrm{dl}$; MCV: $36.5 \mathrm{fl}$; $\mathrm{MCH}$ : 13.3 pg; CMCH: $36.3 \%$; and lymphopenia: $284 \mathrm{x}$ $10^{3} / \mathrm{mm}^{3}$ ) and thrombocytopenia (platelets: $68 \mathrm{x}$ $10^{3}$ ). During the microscopic examination of blood cells, anisocytosis, polychromasia and the presence of ovoid and acidophilic forms, containing a nucleus and kinetoplast, compatible with the amastigote forms of Leishmania spp., were observed within the leukocytes (Figure 1A). The number of leukocytes parasitized in 1,000 nucleated cells revealed a parasitemia of $1 \%$.

Three days after the first consultation, during the recheck, the owner reported a worsening condition, characterized by hyporexy and apathy. In addition to the aforementioned clinical manifestations, the physical examination revealed a weak pulse, an increased CFT of 3 seconds and a body temperature of $39.3{ }^{\circ} \mathrm{C}$. The patient was hospitalized and submitted to intravenous fluid therapy with $0.9 \%$ physiological solution, followed by food supplementation with Hiperkcal Nutricuper Cat 
(Organnact ${ }^{\circledR}$, Brazil), $1 \mathrm{~g}$, orally, once per day, and Eritrós Cat (Organnact $\AA$, Brazil), $1 \mathrm{~g}$, orally, once per day, in addition to an offer of pasty feed.

A second blood count was requested, followed by biochemical tests to evaluate hepatic and renal function. Material from skin scrapings and a puncture of the popliteal lymph node were collected in order to detect the probable Leishmania species present, through molecular analysis. At the time, the animal was treated with a $10 \%$ Imidacloprid collar and $4.5 \%$ Flumethrin $4.5 \%$.

In the second hemogram, hematological abnormalities were observed: hypochromic normocytic anemia (red blood cells: $3.82 \times 10^{6} \%$ $\mathrm{mm}^{3}$; hematocrit: 16.6\%; hemoglobin: $4.8 \mathrm{~g} / \mathrm{dl}$; MCV: $43.5 \mathrm{fl}$; $\mathrm{MCH}$ : $12.6 \mathrm{pg}$; and $\mathrm{CMCH}: 28.9 \%$ ), leukocytosis (leukocytes: 24,600 x $10^{3} / \mathrm{mm}^{3}$ ) by neutrophilia with left deviation (neutrophils segmented: $18,696 \times 10^{3} / \mathrm{mm}^{3}$; rod: $2.214 \times 10^{3} /$ $\mathrm{mm}^{3}$ ), monocytosis (monocytes: $1.476 \times 10^{3} /$ $\mathrm{mm}^{3}$ ), lymphocytosis (lymphocytes: $984 \times 10^{3 /}$ $\mathrm{mm}^{3}$ ) and thrombocytopenia (platelets: $112 \mathrm{x}$ $10^{3} / \mathrm{mm}^{3}$ ). Hematoscopy revealed anisocytosis, polychromasia, hypochromia, macroplots and the presence of amastigote forms of Leishmania spp. within the neutrophils and monocytes.

Figure 1. Visual demonstration of the amastigote forms of Leishmania spp. in tissue specimens of domestic felines from the municipality of Araguaína-TO. Note the protozoa (arrows) in the following types of samples: (A) blood; (B) popliteal lymph node; (C) submandibular lymph node; (D) liver; (E) spleen; (F) lung. (HE, 100X, scale = $6 \mu$ m).
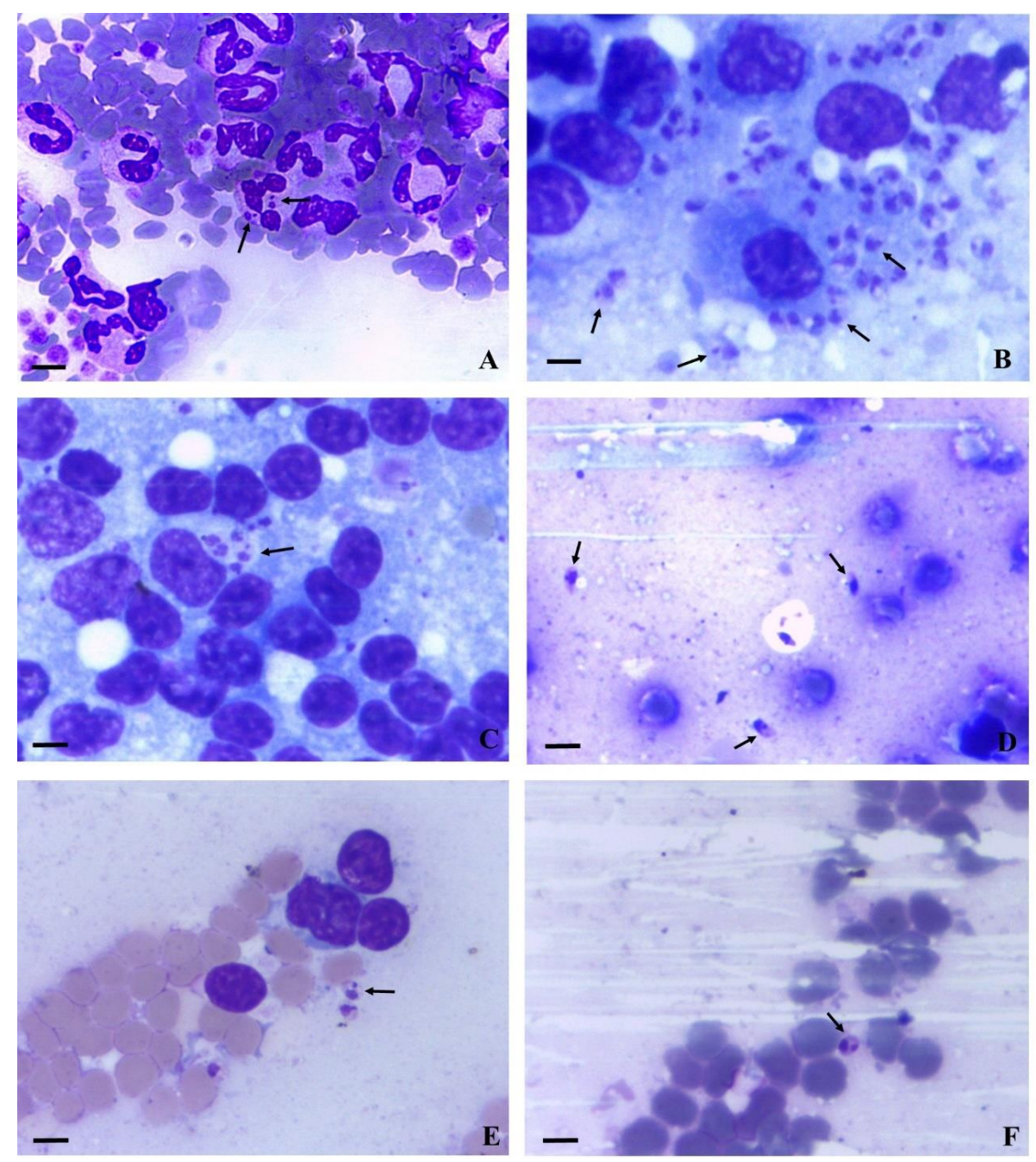
The biochemical analytes were urea, creatinine, alanine aminotransferase (ALT/TGP), aspartate aminotransferase (AST/TGO) and total proteins and fractions (albumin and globulins). Hypocreatinemia (creatinine $0.4 \mathrm{mg} / \mathrm{dl}$ ), hypoproteinemia (total protein: $4.1 \mathrm{~g} / \mathrm{dl}$ ), hypoalbuminemia (albumin: 1.3 $\mathrm{g} / \mathrm{dl}$ ) and increased serum ALT activity (124 IU/L) were found.

After 10 days, the animal demonstrated a worsening clinical picture and died. Then, she was sent to the Veterinary Medicine School and Animal Science of Tocantins Federal University for necropsy. During the procedure, tissue fragments from the liver, spleen, lung, kidney, conjunctiva, skin and popliteal, submadibular and mesenteric lymph nodes were collected.

Imprints of the popliteal and submadibular lymph nodes, liver, spleen and lung were obtained on microscopic slides. These were stained using the rapid Panoptic method and subjected to direct parasitological examination in an immersion objective, which revealed the presence of amastigote forms in all examined tissues (Figure 1B-F). Visually, the popliteal lymph node had the greatest number of amastigote forms. In every 1,000 nucleated cells, we observed 832 Leishmania donovani units (LDU index), an index that is considered high (REIS et al., 2006).

Samples obtained from both the necropsy and clinical examination were submitted to an extraction of total genomic DNA using a GenElute Mammalian Genomic DNA Miniprep Kit (Sigma-Aldrich ${ }^{\circledR}$, United States), according to the manufacturer's recommendations. The subsequent molecular analysis was performed by PCR using primers $\mathrm{MC1}$ (5'-GTTAGCCGATGGTGGTCTTG-3') and MC2 (5'-CACCCATTTTTCCGATTTTG-3'), which amplified a $447 \mathrm{bp}$ specific sequence for $L$. (L.) infantum, according to the methodology described by Cortes et al. (2004).

Amplification occurred in a Veriti 96 Well Thermal Cycler (Applied Biosystems, Thermo
Fisher Scientific ${ }^{\circledR}$, United States) under the following conditions: an initial denaturation cycle of $95{ }^{\circ} \mathrm{C}$ for $5 \mathrm{~min} ; 40$ repeated cycles of $95{ }^{\circ} \mathrm{C}$ for $30 \mathrm{~s}, 61^{\circ} \mathrm{C}$ for $30 \mathrm{~s}$ and $72{ }^{\circ} \mathrm{C}$ for $1 \mathrm{~min}$; and a final extension cycle of $72{ }^{\circ} \mathrm{C}$ for $10 \mathrm{~min}$. To read the reaction, $10 \mu \mathrm{L}$ of the PCR products were homogenized in $2.5 \mu \mathrm{L}$ of $2.5 \%$ bromophenol blue and applied on a $1.5 \%$ agarose gel (Agarose LE, Uniscience ${ }^{\circledR}$, Brazil) containing $3.8 \mu \mathrm{L}$ of ethidium bromide. Electrophoresis was conducted in an electrophoresis tub (Bio-Rad $\AA$, United States) under $140 \mathrm{~V}$ for $5 \mathrm{~min}$, followed by a $45-\mathrm{min}$ period at $110 \mathrm{~V}$. Visualization was performed by means of an UV light transilluminator. Molecular analysis showed that all tested samples were positive (Figure 2).

Given the study of the presence of more Leishmania species, a cutaneous tissue sample was subjected to a second PCR using primers 150 (5'-GGG(G/T)AGGGGCGTTCT(C/G)CGAA-3') and $152\left(5^{\prime}-(\mathrm{G} / \mathrm{C})(\mathrm{G} / \mathrm{C})(\mathrm{G} / \mathrm{C})(\mathrm{A} / \mathrm{C}) \mathrm{CTAT}(\mathrm{A} / \mathrm{T})\right.$ TTACACCAACCCC-3'), which amplify 120 bp of the conserved region of the kinetoplast minicircle (kDNA) of Leishmania spp. (PASSOS et al., 1999). The DNA of the strains L. (L.) amazonensis (IFA/BR/1967/PH8), L. (V.) braziliensis (MHOM/ BR/2003/IMG) and L. (L.) chagasi (MHOM/BR/74/ PP75) were used as positive controls.

Amplification occurred in a Mastercycler Personal (Eppendorf®, Germany) thermal cycler with an initial denaturation cycle of $94{ }^{\circ} \mathrm{C}$ for $5 \mathrm{~min}$; 35 repeated cycles of $94{ }^{\circ} \mathrm{C}$ for $45 \mathrm{~s}, 59{ }^{\circ} \mathrm{C}$ for 45 $\mathrm{s}$ and $72{ }^{\circ} \mathrm{C}$ for $30 \mathrm{~s}$; and a final extension cycle of $72{ }^{\circ} \mathrm{C}$ for $7 \mathrm{~min}$. The result was visualized after electrophoresis in $6 \%$ polyacrylamide gel and $0.2 \%$ silver staining. The positive sample was submitted to restriction fragment length polymorphism (RFLP-PCR) analysis using the restriction endonuclease Hae III to observe the band pattern for the Leishmania species (VOLPINI et al., 2004). Three fragments (60 bp, $80 \mathrm{bp}$ and $120 \mathrm{bp}$ ) were formed, demonstrating that only $L$. (L.) Infantum species were present in the tested sample. 
Figure 2. Polymerase chain reaction for Leishmania (Leishmania) infantum in tissue specimens from a domestic feline from the municipality of Araguaína-TO. Note the following: (M) molecular weight marker of $100 \mathrm{bp}$; (1) positive control, strain P75; (2) blood; (3) conjunctive biopsy; (4) spleen biopsy; (5) liver biopsy; (6) lung biopsy; (7) kidney biopsy; (8) lymph node aspirate; (9) popliteal lymph node biopsy; (10) submandibular lymph node biopsy; (11) mesenteric lymph node biopsy; (12) deep skin scraping; (13) skin biopsy; (14) negative control. The positivity of all tested samples (wells 2 to 13) was evaluated by the distribution of the bands at a height of $447 \mathrm{bp}$.

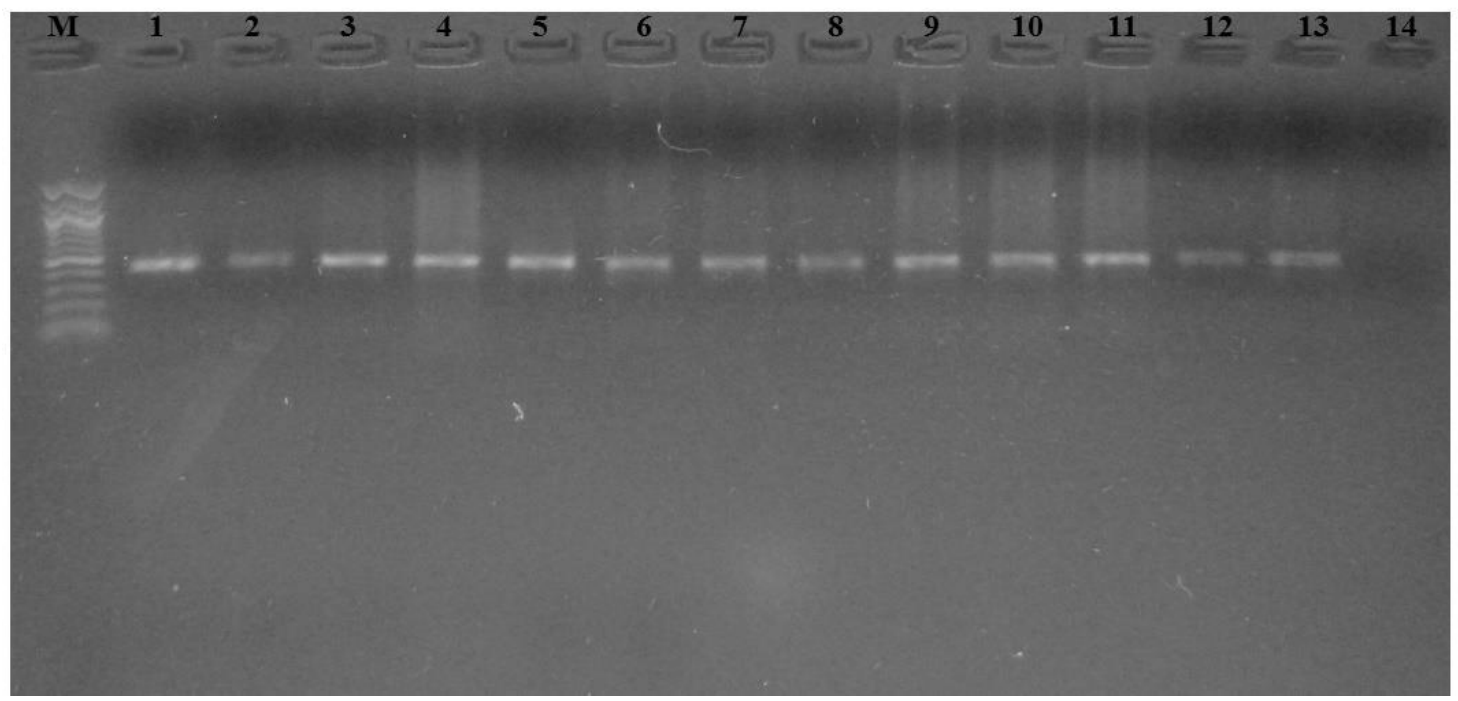

Serum samples were submitted to an indirect immunofluorescence reaction (IFR) based on the methodology described by Pedras et al. (2008), considering a titer $\geq 1: 40$ as a positive sample. The obtained titer was 1:160.

In order to obtain knowledge of a possible association between infections, the serum of the animal was also tested for feline immunodeficiency virus (FIV) and feline leukemia virus (FeLV). For this, a SNAP FIV/FeLV Combo Test (IDEXX®, United States) was used. Despite infection by L. (L.) infantum, the result for FIV/FeLV was negative.

In this report, the infection by the protozoan L. (L.) infantum was observed in a two-monthold female domestic feline, of an undefined breed. Tissues such as blood, conjunctiva, spleen, liver, popliteal, submandibular and mesenteric lymph nodes, skin, lung and kidney were all positive. Despite the presence of the parasite in all organ samples, the observed clinical signs were nonspecific and differ from those reported in the literature; the literature outlines that ocular secretion and nodular, ulcerative or crust lesions (in regions such as the nose, lips, ears and eyelids), paralysis of generalized dermatitis, hyperkeratosis, generalized ventral alopecia, nasal discharge, presence of the feline respiratory complex, uveitis, ear-tip lesions and gingivostomatitis are generally observed (NASEREDDIN et al., 2008; SHERRY et al., 2011).

Even with few clinical signs, the animal's condition rapidly evolved to death, which characterizes an acute evolution of the disease. Thus, the infection may be active in clinically normal animals or those with clinical signs, being cutaneous, ocular and/or systemic (CHATZIS et al., 2014).

Another relevant fact is the age of the feline. The possibility of infection in any age group has already been reported (SOBRINHO et al., 2012). Thus, the present description supports the fact that there is no minimum or maximum age for infection, and that the hypothesis of vertical transmission should be investigated. 
With respect to the analysis performed via PCR, during the study of a case of feline leishmaniasis in Minas Gerais state, Silva et al. (2010) obtained results similar to those shown here. The authors observed positive samples from the marrow, skin, liver, spleen, popliteal lymph node and kidneys. However, it should be noted that the results of this report also include positive blood and skin scrapings obtained from the veterinary clinic office, which may be of great help in the establishment of a reliable and less invasive diagnosis using a specific PCR for $L(L)$ infantum.

In the case of alterations evidenced by clinical pathology, normocytic anemia is frequently reported in cases of feline LV and hypoalbuminemi, and increased serum ALT activity may occur (PENNISI et al., 2015). Similarly, neutrophilic leukocytosis is observed in the clinical form of the infection (SILVA et al., 2010). Thus, these parameters may be of value for the clinical diagnosis of the disease.

Here, we described the presence of amastigote forms of Leishmania in $1 \%$ of the leukocytes visualized in the blood smear. Compared to this data, in a cat from Portugal, $4 \%$ of the neutrophils from the leukocyte smear contained the protozoan (PENNISI et al., 2015). Findings of this nature are relevant since they are not routine in the clinic environment.

Co-infection of L. (L.) infantum and FIV is frequently reported (SOBRINHO et al., 2012), but this was not observed in the studied animal, since the results for both FIV and FeLV were negative. In this way, it is possible that the death of the animal occurred solely because of multiple organ failure due to Leishmania infection.

This report addresses the first case of feline leishmaniasis in Tocantins state and provides an alert for veterinarians working in endemic regions or with risky transmission; it reveals that kittens can become infected and develop the disease, with rapid evolution and a high index of parasitism. When considering the use of PCR as a method of molecular analysis, obtaining skin scrapings and blood samples is of value for a less invasive diagnosis in cats.

\section{Acknowledgments}

We wish to acknowledge the AnimaLe veterinary analysis laboratory for having contributed to the accomplishment of the complementary examinations, the veterinary clinic Bichos e Cia for the partnership offered, and Dra. Miriam Leandro Dorta and Msc. Cálita Marques of the Instituto de Patologia Tropical e Saúde Pública da Universidade Federal de Goiás (IPTSP-UFG) for providing training for the molecular analyses and for providing the reference strains of Leishmania spp.

\section{References}

BRASIL. Coeficiente de incidência de Leishmaniose Visceral, por 100.000 habitantes. Brasil, Grandes Regiões e Unidades Federadas. 1990 a 2015. Brasília: Brasil, 2017. Disponível em: http://portalarquivos. saude.gov. br/images/pdf/2016/novembro/08/LV-Coeficiente $\% 20$ de\%20Incidncia.pdf. Acesso em: 1 abr. 2017.

CHATZIS, M. K.; ANDREADOU, M.; LEONTIDES, L.; KASABALIS, D.; MYLONAKIS, M.; KOUTINAS, A. F.; RALLIS, T.; IKONOMOPOULOS, J.; SARIDOMICHELAKIS, M. N. Cytological and molecular detection of Leishmania infantum in different tissues of clinically normal and sick cats. Veterinary Parasitology, Amsterdam, v. 28, n. 202, p. 217-225, 2014. DOI: $10.1016 /$ j.vetpar.2014.02.044

CORTES, S.; ROLÃO, N.; RAMADA, J.; CAMPINO, $\mathrm{L}$. PCR as a rapid and sensitive tool in the diagnosis of human and canine leishmaniasis using Leishmania donovani s.l.-specific kinetoplastid primers. Transactions of the Royal Society Tropical Medicine and Hygiene, London, v. 98, n. 1, p. 12-17, 2004. DOI: 10.1016/S00359203(03)00002-6

NASEREDDIN, A.; SALANT, H.; ABDEEN, Z. Feline leishmaniasis in Jerusalem: serological investigation. Veterinary Parasitology, Amsterdam, v. 158, n. 4, p. 364369, 2008. DOI: 10.1016/j.vetpar.2008.09.022

PASSOS, V. M. A.; FERNANDES, O.; LACERDA, P. A. F.; VOLPINI, A. A.; GONTIJO, C. M. F.; DEGRAVE, W.; ROMANHA, A. J. Leishmania (Viannia) braziliensis 
is the predominant species infecting patients with American cutaneous leishmaniasis in the State of Minas Gerais, Southeast Brazil. Acta Tropica, Amsterdam, v. 72 , n. 3, p. 251-258, 1999. DOI: 10.1016/S0001706X(98)00100-4

PEDRAS, M. J.; GOUVÊA VIANA, L. de; OLIVEIRA, E. J. de; RABELLO, A. Comparative evaluation of direct agglutination test, rK39 and soluble antigen ELISA and IFAT for the diagnosis of visceral leishmaniasis. Transactions of the Royal Society of Tropical Medicine and Hygiene, London, v. 102, n. 2, p. 172-178, 2008. DOI: $10.1016 /$ j.trstmh.2007.11.004

PENNISI, M. G.; CARDOSO, L.; BANETH, G.; BOURDEAU, P.; KOUTINAS, A.; MIRÓ, G.; OLIVA, G.; SOLANO-GALLEGO, L. LeishVet update and recommendations on feline leishmaniosis. Parasites \& Vectors, London, v. 8, n. 1, p. 302, 2015. DOI: 10.1186/ s13071-015-0909-z

REIS, A. B.; MARTINS-FILHO, O. A.; TEIXEIRACARVALHO, A.; CARVALHO, M. G.; MAYRINK, W.; FRANÇA-SILVA, J. C.; GIUNCHETTI, R. C.; GENARO, O.; CORRÊA-OLIVEIRA, R. Parasite density and impaired biochemical/hematological status are associated with severe clinical aspects of canine visceral leishmaniasis. Research in Veterinary Science, Oxford, v. 81, n. 1, p. 68-75, 2006. DOI: 10.1016/j. rvsc.2005.09.011
SHERRY, K.; MIRO, G.; TROTTA, M.; MIRANDA, C.; MONTOYA, A.; ESPINOSA, C.; RIBAS, F.; FURLANELLO, T.; SOLANO-GALLEGO, L. A Serological and molecular study of Leishmania infantum infection in cats from the Island of Ibiza (Spain). VectorBorne and Zoonotic Diseases, New York, v. 11, n. 3, p. 239-245, 2011. DOI: 10.1089/vbz.2009.0251

SILVA, S. M. da; RABELO, P. F. B.; GONTIJO, N. D.; RIBEIRO, R. R.; MELO, M. N.; RIBEIRO, V. M.; MICHALICK, M. S. M. First report of infection of Lutzomyia longipalpis by Leishmania (Leishmania) infantum from a naturally infected cat of Brazil. Veterinary Parasitology, Amsterdam, v. 174, n. 1-2, p. 150-154, 2010. DOI: 10.1016/j.vetpar.2010.08.005

SOBRINHO, L. S.; ROSSI, C. N.; VIDES, J. P.; BRAGA, E. T.; GOMES, A. A.; LIMA, V. M. de; PERRI, S. H.; GENEROSO, D.; LANGONI, H.; LEUTENEGGER, C.; BIONDO, A. W.; LAURENTI, M. D.; MARCONDES, M. Coinfection of Leishmania chagasi with Toxoplasma gondii, Feline Immunodeficiency Virus (FIV) and Feline Leukemia Virus (FeLV) in cats from an endemic area of zoonotic visceral leishmaniasis. Veterinary Parasitology, Amsterdam, v. 187 , n. 1-2, p. 302-306, 2012. DOI: 10.1016/j.vetpar.2012.01.010

VOLPINI, Â. C.; PASSOS M. V.; OLIVEIRA, G. C.; ROMANHA, A. J. PCR-RFLP to identify Leishmania (Viannia) braziliensis and L. (Leishmania) amazonensis causing American cutaneous leishmaniasis. Acta Tropica, Amsterdam, v. 90, n. 1, p. 31-37, 2004. DOI: 10.1016/j. actatropica.2003.10.008. 
